\title{
The Role of Higher Education in the Formation of the Professional Capacity of Young People
}

\section{Sarsenovaa $\mathrm{AB}^{*}$, Abdikerovab GO and Sadyrovac MS}

Department of Pre-College Education, Al-Farabi Kazakh National University, Almaty, Kazakhstan

"Corresponding author: Sarsenovaa AB, Department of Pre-College Education, Al-Farabi Kazakh National University, Almaty, Kazakhstan, Tel: $+7(727) 3773337$; Email: aselek_82@bk.ru

Received date: April 27, 2016; Accepted date: May 12, 2016; Published date: May 18, 2016

Copyright: (c) 2016 Sarsenovaa AB, et al. This is an open-access article distributed under the terms of the Creative Commons Attribution License, which permits unrestricted use, distribution, and reproduction in any medium, provided the original author and source are credited.

\begin{abstract}
This article defines the research methodology and measurement technology of the professional capacity of young people, and substantiates the concept of 'professional potential of an expert'. Taking into consideration person's professional qualification, the professional capacity is seen as a form of human capabilities in the field of labor relations, which is formed only as a result of training in high school. The article reveals the problems of the future experts associated with employment in the Republic of Kazakhstan and the relationship between the labor market and education. This publication provides the major indicators, identified through sociological research, contributing to the formation and development of the professional capacity of graduates of Kazakhstan.
\end{abstract}

Keywords: Young people; Professional capacity; Higher education; Graduate

\section{Introduction}

The study analyzes the state and the development of the graduates' professional capacity. This problem is associated with the study of employment of young people in the labor market of Kazakhstan. In a sociological aspect, the suggested issue involves the problem of professional formation of the future expert.

The article presents the role of the higher education in the formation of the professional capacity of the young people of Kazakhstan.

One of the priorities of the state policy in Kazakhstan is the full development of the potential of young people. Due to the growing labor market competition, increasing requirements for the employment and career development of young people, increasing complexity of international cooperation in the professional field, the search of the possibilities of the professional capacity becomes very important.

This publication aims to identify key indicators contributing to the formation and development of the professional capacity of graduates of Kazakhstan through sociological analysis.

\section{Consequently, the following tasks are to be implemented:}

- To assess the role of higher education in the development of the future professionals;

- To analyze the current trends in the study of professional capacity and youth employment;

- To identify the main positive and negative factors affecting the level of professional capacity.

\section{Method of Research}

Sources which became an empirical base for the study are as follows: Desk study or traditional document analysis. We analyzed documents, statistical books, the results of sociological research, performed by the authors from June to July 2015 and which were published by the Statistical Agency of the Republic of Kazakhstan in the southern region of Kazakhstan, Almaty and Shymkent.

The need for regulation of the formation of professional capacity of young people in higher education institution primarily motivates to reflect on issues of theoretical and methodological basis of professional capacity, which will allow developing a suitable social control mechanism.

According to the new reform, the educational system of Kazakhstan is brought as close to the American and European standard as possible. The reform takes into account the national peculiarities of Kazakhstan without excluding traditions and historical experience.

The main task of higher education is to form comprehensive social personality traits, preparing professionals who can work successfully in a modern high-tech manufacturing, manage people, organize economic, social and political processes in a positive direction and develop culture for the benefit of people and society. The role of higher education as a leading factor in the formation of human capital significantly increases in the market environment.

Studying the development of professional capacity of university graduates as a basis for the formation of the intellectual potential becomes more important due to the growing demands to receive higher professional education.

\section{Problem Statement}

Among subpotential of social potential the understanding of the category "professional capacity" is of practical and theoretical importance. Sociology considers potential as a set of spiritual and material resources contributing to the achievement of certain goals. Potential is an internal source, a spiritual reservoir of an individual which can be used to achieve any goal and make relevant decisions.

Bente Abrahamsen and Ida Drange [1] study sheds light on how ethnic minority students in Norway seek to navigate occupational 
opportunities after graduating from professional bachelor programs. Students' career ambitions and career expectations are investigated. The study adopts a comparative approach and includes students of Asian origin and western minority students as well as majority students. The findings show that ethnic minorities have higher career ambitions than majority students, but their career expectations are not correspondingly high. The study identifies ethnicity both as a resource (ethnic capital) and as an obstacle in the pursuit of a professional career. Structural disadvantages such as perceived discrimination seem to curb the utility of ethnic capital in capitalizing on occupational opportunities, particularly for managerial positions. Ethnicity as a resource seems to play a role among both Asian and western minority students, and appears particularly strong in the development of career ambitions and in the efforts to pursue educational qualifications.

Describing the contemporary models of work and employment, Nabil Khattab and Steve Fenton [2] consider them to be fragmented and unstable. For them, satisfaction with life is the key factor of employment. They studied 1100 young people by identifying the relationship between employment, unemployment and life satisfaction. Fixed variables of employment are significantly associated with life satisfaction, and the variables of unemployment are associated with public relations and satisfaction with family relationships.

It is precisely the formal introduction of education policy that forms the new element to the strategy of "policy mix" in the fight against unemployment, particularly amongst young people. It is now widely held that alone, economic policy for growth and greater labor market flexibility does not guarantee an increase in the competitiveness of a country. However competitiveness can be improved by the existence of a better educated workforce with a high rate of employment mobility. In this case human capital can be enhanced through informal interaction such as work experience which allows young people to become a workforce with higher levels of productivity, more able to meet the requirements of potential employers. From the European Employment Strategy it is clear that in order to be effective and useful, professional and vocational training must be widespread as is the case in Scandinavia. For example, in Holland training programs are continually upgraded and revised in order to meet the requirements of young people, faced with entering an ever changing labor market [3].

The article of Gnevasheva [4] provides social component of higher education, which reflects young people's perception of higher institution as an agent of labor socialization, and the higher education as a value, which has deep social significance in the hierarchy of values of modern society. On the basis of author's research Gnevasheva determined the scientific and practical background as well as the theoretical and methodological basis to the interpretation of contemporary features of public perception of higher education institutions in the system of youth labor socialization and professional education as a value in the formation of professional competencies provided by this system.

Gavrilyuk and colleagues [5] define professional capacity as a form of manifestation of human potential in the field of labor relations. The authors point out that receiving education in higher education institution, the young man acquires multiple thesauri, contributing to the accumulation of professional capacity, which, in a particular situation, involves the thesaurus generalization - a composition of the thesaurus structures, concepts and standard events that provide some impetus for orientation in professional field of expertise.
The analysis of modernization processes of the society of Kazakhstan, the growth of both the role and the importance of accessibility of education as a factor of social mobility and the factor of the formation of human capital, the assessment of social and stratification processes in Kazakhstan are reflected in the studies of Azhenov [6] and Sadyrova [7]. The problems of education in the age of globalization and its role in the formation of students as human capital are reflected in the works of Kaldybaeva [8], Abdiraymova [9] and Aralbaeva [10].

As we can see, studying the professional capacity of young people remains a topical problem for the scientists from different countries. Considering the theoretical and methodological basis of this problem it should be noted that the problem of formation of the professional capacity is not yet sufficiently understood. Competitive market economy requires training of experts possessing professional capacity.

\section{Higher School of Kazakhstan in the System of Formation of Professional Capacity of University Graduates}

Changes of the modern society come along with the changes in the requirements of the system of education in general. Education has important social functions in the modern information society (person's continuing education in the field of communication technologies, communication between individuals and social institutions, the technological development of information society, etc.) and in this sense, acts as a functional mechanism providing further development of modern society. First of all, there are changes in the purpose of education, which now tends to provide the conditions for selfdetermination and self-realization rather than knowledge. This statement is based on the change in the attitude towards the person as a complex system and towards the knowledge that must be addressed to the future, and not to the past.

Strategic development program of Kazakhstan until 2030, the State Program for Education Development of the Republic of Kazakhstan for 2011-2020 are the basis of the modern educational policy of the Republic of Kazakhstan.

It is the level of the development of higher education in the country which determines the intellectual potential of society and the related scientific, technological, economic and general cultural progress. The process of preparing experts with higher education, as well as any other process needs to be managed. To implement such important management functions as planning, organization, control and regulation, first of all, you must have the appropriate tools for assessing the current level of efficiency of this process. In this regard, the issues related to the development of science-based mechanism and a system of indicators to assess the socio-economic efficiency of the sphere of higher education become even more important. This will allow making necessary changes in the higher education in accordance with the changing conditions and requirements. In the light of the definition of the category "efficiency", there is an objective need for its evaluation, not only in manufacturing but also in other areas of human activity, including the field of education. Since, firstly, the process of training specialists has similarities with the production process (to train specialists certain material, financial and human resources are spent, and trained professional personnel (their labor force) as the final useful result of the system of education, serves as an item of goods in the market conditions), and, secondly, the mechanism to evaluate the economic efficiency of production is developed in the most complete 
Page 3 of 5

and scientifically based way, the necessity to study the "efficiency" (in terms of performance and economic effectiveness of the implemented process) occurs.
Structure and intellectual potential of the education system of Kazakhstan is reflected in Table 1.

\begin{tabular}{|c|c|c|c|c|c|c|}
\hline & 2007 & 2008 & 2009 & 2010 & 2011 & 2012 \\
\hline The number of post graduate students & 142 & 142 & 106 & 102 & 49 & 20 \\
\hline The number of PhD students & 303 & 366 & 508 & 439 & 666 & 960 \\
\hline $\begin{array}{l}\text { The number of applicants for a degree of Candidate } \\
\text { of Sciences }\end{array}$ & 4090 & 7751 & 10103 & 6619 & 4207 & 2488 \\
\hline The number of students & 717053 & 633814 & 610264 & 620442 & 629507 & 571691 \\
\hline Graduates & 178,4 & 196,7 & 176,1 & 161,9 & 160,9 & 171,6 \\
\hline The number of higher-education teaching personnel & 42788 & 41207 & 37814 & 39600 & 40531 & 41224 \\
\hline The number of students in colleges & 499546 & 504742 & 495163 & 490997 & 491711 & 520371 \\
\hline The number teaching staff (full-time) & 31560 & 33200 & 33096 & 32218 & 28360 & 34416 \\
\hline $\begin{array}{l}\text { The number of children in permanent pre-school } \\
\text { institutions }\end{array}$ & 232925 & 257053 & 274905 & 390791 & 489380 & 584305 \\
\hline $\begin{array}{l}\text { The number of teaching staff in permanent pre- } \\
\text { school institutions }\end{array}$ & 24089 & 27277 & 29862 & 42408 & 52777 & 63304 \\
\hline \multicolumn{7}{|c|}{$\begin{array}{l}\text { *Social and economic development of the Republic of Kazakhstan. (A brief statistical bulletin) January-December, 2012. Statistics Agency of the Republic of } \\
\text { Kazakhstan. pp. 46. Astana, } 2013\end{array}$} \\
\hline \multicolumn{7}{|c|}{$\begin{array}{l}\text { * Social and economic development of the Republic of Kazakhstan. (A brief statistical bulletin) January-December, 2013. Statistics Agency of the Republic of } \\
\text { Kazakhstan. Astana, } 2014\end{array}$} \\
\hline
\end{tabular}

Table 1: The dynamics of the education system of Kazakhstan.

Higher education is becoming more prestigious. It is available only for those who have a high standard of living and social status. This implies the relevance of the study of human capital development of students through the expansion of their social, economic and cultural opportunities.

\section{Indicators of the Professional Capacity of Graduates on the Basis of Sociological Research}

The indicators are obtained as a result of sociological research, which aims to identify the role of the university in the formation of the professional capacity. The analytical material was prepared on the basis of a public opinion poll among graduates and young professionals. The survey included 300 graduates in 6 high schools, $73.3 \%$ - female and $23.7 \%$-male.

One of the directions of education modernization concept is the quality of specialist training, i.e., the quality of education at universities. The table below presents the main indicator-satisfaction with the quality of education at the university.

During this survey the graduates were asked a general question about their overall satisfaction with the level of education. The total result can be considered as quite high $-70.9 \%$. Of these $48.8 \%$ were totally satisfied. $7.4 \%$ of students expressed a negative opinion. About $1.0 \%$ of the respondents were absolutely unsatisfied with the knowledge they acquired. As we can see $16.1 \%$ of graduates of Kazakhstan universities who participated in the survey find it difficult to estimate the quality of education, adhering to a neutral position: "It's not that I'm satisfied or unsatisfied."
The results also show that more than one in ten students in general and, in particular, is satisfied with the process of acquiring the professional education. This study also presents the ranking of the most important skills required for the preparation of students in the conditions of intensive development of the modern economy. The respondents identified the study of foreign languages and the computer courses as the most required for the future professional activity skills and knowledge. So, almost half of the respondents consider learning of a foreign language as an important aspect of education $-28.0 \%$.

Then, in the descending order they named the computer courses $-27.6 \%$, additional education to those who have secondary or higher professional education $-19.9 \%$, the second higher education $-14.7 \%$, dual-degree education $-8.0 \%$.

Among graduates, entering the university is one of the main conditions for the further self-realization and personal growth in the labor market. According to the survey, the graduates are primarily focused on the desire to get a profession and higher education as a tool to achieve their goals in life. Almost every second student with a higher education was guided by the desire to obtain a diploma of this university, which implies the determination to pursue higher education at the university they have chosen. Along with this it is also important that higher institutions prepare competitive specialists.

The professional competence and potential are necessary for the successful implementation of professional activity in the future work of the graduate. The survey reveals that practical training, the introduction in the educational process of IWS (independent work of student) and IWSL (independent work of student with lecturer) affect the formation of professional capacity. If, during practical training the 
students' independent work is organized in accordance with the process approach and corresponds to the activities of specialists in solving professional problems, it will facilitate both the development of the professional capacity and the improvement of the efficiency of practical training. According to the survey for the majority of graduates (44.3\%), practical training has affected professional socialization of students. This survey shows that the impact of practical training is quite significant. $43.1 \%$ of the respondents believe that the introduction into the educational process of IWS and IWSL, to a large extent, influenced the formation of professional capacity. $40.3 \%$ of the respondents think that their professional development was not that strongly influenced by IWS and IWSL. $13.8 \%$ of the respondents deny the role of IWS and IWSL as a form of learning process.

It should also be noted that for graduates the dominant factor of the personal importance in the future work becomes the ability to earn money, to have it to meet one's personal needs $-32.3 \%$ of graduates identified this factor as one of the leading, which is explained by the orientation of young people on material success and prosperity. Approximately $22.0 \%$ of the surveyed graduates are focused on the career opportunities, and every fifth graduate is focused on the possibility of self-realization (12.3\%), to manifest oneself.

One of the main survey questions is if the future young professionals stick to the profession they have chosen. The vast majority of graduates stick to their specialty and plan to work within one's specialty in the future (53.7\%). $16.9 \%$ believe that it is not necessary to work within one's specialty, and $12.2 \%$ are planning to continue their education (Master's Degree), $10.1 \%$ are targeted towards receiving second higher education, $5.7 \%$ are planning to continue their studies abroad.

The questionnaire allows us to estimate the role of higher education in the formation of the graduates' professional capacity, the degree of satisfaction with the quality of education, employment of graduates in the specialty. According to the data of this sociological research we formed a list of indicators which fully reflect the process of employment of graduates and identify the main trends in the behavior of young professionals when it comes to the junction of the education market and the labor market. These indicators directly characterize the subject area of the research and the professional qualities of graduates, which play an important role in the employment.

\section{Conclusion}

Improving the quality of education and training of highly qualified, competitive and mobile in the labor market specialists are the main tasks of the universities. According to the analysis of the state of professional capacity of young people we suggest:

- To develop a methodology for the study of professional capacities in the system of higher education;

- To undertake a sociological analysis of the role of higher education in the formation of the professional capacity of Kazakhstan;

- To investigate the factors of realization of higher education in the Republic of Kazakhstan taking into account the international experience and the needs of innovative development;

- To develop concepts of the higher education system of the Republic of Kazakhstan, focused on the formation of professional capacity of high-quality.

The questionnaire survey shows the main indicators of the role of universities in the formation of specialists:
- This research reveals the most significant factors, which currently have the greatest impact on the selection of the representatives of the younger generation of their future profession. In general, graduates are focused on the desire to get a profession and the desire to obtain a diploma of high school, in which they are trained. This indicator shows that the majorities of students has made a conscious choice and intend to work within their chosen specialty.

- The results of the questionnaire show the need to improve the methods of IWS and IWSL as well as to improve practical training in the educational process.

- According to the survey the majority of respondents are satisfied with the level of education received. About $1 \%$ of the respondents note that the higher education does not correspond to the requirements of world standards of the educational process.

- The opportunity to earn money and career development became the leading motives in the future work of graduates.

- The researchers have made the rating of the main ways to find work, which graduates will use in the future; i.e., among young generation the material values stand first on the list.

\section{Acknowledgement}

This article aims to distribute some of the results obtained in the framework of the fundamental research of the Ministry of Education and Science of the Republic of Kazakhstan on " Professional potential of young people in the context of Kazakhstan's intellectual nation formation: by-region sociological study".

\section{References}

1. Abrahamsen B, Drange I (2015) Ethnic minority students' career expectations in prospective professions: navigating between ambitions and discrimination. Sociology 49: 252-269.

2. Khattab N, Fenton S (2009) What makes young adults happy? employment and non-work as determinants of life satisfaction. Sociology 43: 11-26.

3. Refrigeri L, Aleandri G (2013) Educational policies and youth unemployment. Procedia-Social and Behavioral Sciences 93: 1263-1268.

4. Gnevasheva VA (2012) Development of the youth segment of the labor market through the development of professional competencies through the system of higher education.

5. Gavrilyuk VV (2012) Professional capacity of young teachers of provincial schools-collective monograph p. 182.

6. Azhenov MS, Sadyrova MS, Omarova A (2011) Sociology of Education. Coursebook-Almaty p. 96.

7. Sadyrova MS, Taubaeva ME (2014) Social changes in the social structure of modern Kazakhstan. Collection of materials of the 5th Congress of Sociologists of Kazakhstan "Strategy Kazakhstan-2050"-social development, Almaty pp: 387-393.

8. Kaldybaeva TZ (1997) Sociology of Education. Almaty p. 206.

9. Abdyraimova G, Sadyrova M (2013) Young scientists in Kazakhstanvocational training and Postdoctoral activity-rgebnissesoziologischer investigations, Political, sociological and legal problems of Gesellschaftsentsentwicklung Kazakhstan. Innovation and gesellscaftliche Entwicklungim modern Kazakhstan, Berlin pp: 126-137.

10. Aralbaeva RK (2006) Higher education as a social institution. Monograph, Taldykorgan p. 116. 